\title{
Perencanaan Persediaan Bahan Baku Produk Makanan dengan Mempertimbangkan Masa Kedaluwarsa dan Unit Diskon di PT.X
}

\author{
Sri Suci Yuniar \\ Teknik Industri Institut Teknologi Nasional, Bandung, Indonesia \\ Email: suciyuniar@itenas.ac.id
}

Received 22 April $2020 \mid$ Revised 31 Mei $2020 \mid$ Accepted 31 Mei 2020

\begin{abstract}
ABSTRAK
Perencanaan persediaan bahan baku pada industri makanan yang memiliki masa kedaluwarsa merupakan salah satu hal yang sangat penting untuk dilakukan. Hal ini disebabkan oleh berkurangnya nilai seiring berjalannya waktu yang diakibatkan oleh bahan baku makanan yang kedaluwarsa. Ketika bahan baku tersebut telah melewati batas kedaluwarsa, maka bahan baku tersebut tidak dapat digunakan sehingga menimbulkan biaya kedaluwarsa yang besar dan terjadinya kekurangan bahan baku yang dapat menimbulkan kerugian kehilangan penjualan. Perusahaan harus dapat menentukan jumlah pemesanan yang tepat sehingga dapat mengurangi biaya-biaya yang diakibatkan oleh bahan baku kedaluwarsa, Pada penelitian ini akan dibahas mengenai suatu model matematis persediaan yang mempertimbangkan faktor kedaluwarsa dan penawaran diskon harga bahan baku yang ditawarkan oleh pemasok ke perusahaan dengan jumlah pembelian tertentu. Hasil dari penelitian ini adalah menentukan kuantitas pemesanan bahan baku yang optimal dan lama waktu siklus pemesanan yang optimal yang dapat meminimumkan total biaya persediaan bahan baku per tahun.
\end{abstract}

Kata kunci: Persediaan, masa kedaluwarsa, unit diskon, lost sales

\begin{abstract}
Planning the supply of raw ingredient in the food industry that has an expiration period is one of the most important things to do. This is caused by the decrease in value over time due to expired raw ingredient. When the raw ingredient has passed the expiry date, then the raw ingredient cannot be used, causing huge expiration costs and a shortage of raw ingredients that can result in loss of sale volume. Companies must be able to determine the right amount of ordering so that it can reduce the costs caused by expired raw ingredients. This research will discuss a mathematical model of inventory that takes into account expiration factors and offers discounts on raw ingredient prices offered by suppliers to companies by the order quantity. The results of this study are to determine the optimal quantity of raw ingredient ordering and the optimal length of the order cycle that can minimize the total cost of inventory of raw ingredients per year.
\end{abstract}

Keywords:inventory, expired time, unit discout, lost sales 


\section{PENDAHULUAN}

Pengendalian persediaan bagi perusahaan yang menyediakan produk-produk yang memiliki masa kedaluwarsa seperti bahan makanan, obat-obatan, dan bahan kimia menjadi faktor yang paling penting untuk diperhatikan. Produk yang termasuk kedalam perishable item ini nilainya akan berkurang seiring berjalannya waktu akibat adanya masa kedaluwarsa. Ketika suatu produk telah melewati masa kedaluwarsa, maka produk tersebut sudah tidak memiliki lagi nilai jual yang dapat menyebabkan kerugian bagi perusahaan.

PT.X merupakan sebuah perusahaan yang bergerak di industri makanan yang memiliki waktu kedaluwarsa tidak lebih dari 1 (satu) minggu. Pada kenyataannya, perusahaan seringkali mengalami kerugian akibat produk kedaluwarsa yang tidak dapat dijual. Hal ini mendorong perusahaan untuk dapat melakukan perencanaan persediaan bahan baku yang tepat dengan cara melakukan pemesanan bahan baku ke pemasok dalam jumlah yang tepat pada waktu yang tepat. Jika perusahaan melakukan pemesanan dengan jumlah lebih besar dari kebutuhan maka dapat menimbulkan biayapersediaan yang besar, sedangkan jika terjadi kekurangan persediaan maka dapat menimbulkan kerugian yang terjadi akibat lost sales (kehilangan penjualan).

Pemasok bahan baku PT.X seringkali memberikan penawaran diskon harga bahan baku yang dijual. Pemberian diskon diberikan apabila jumlah pemesanan bahan baku yang dilakukan perusahaan semakin banyak. Dengan adanya diskon akan dapat memberikan keuntungan bagi perusahaan karenadapat menurunkan biaya bahan baku. Tetapi jika pemesanan bahan baku berlebih maka biaya persediaan akan semakin besar. Sebaliknya jika jumlah pemesanan kurang maka akan terjadi lost sales. Sehingga perusahaan harus dapat menentukan berapa jumlah persediaan bahan baku optimal berdasarkan masa kedaluwarsa dan unit diskon.

Metode Economic Order Quantity (EOQ) adalah sebuah metode persediaan yang dapat digunakan untuk mengetahui berapa jumlah persediaan yang optimal yang dibutuhkan perusahaan Sudah banyak penelitian yang dikembangkan dalam model EOQ, salah satunya EOQ dengan mempertimbangkan masa kedaluwarsa dan pemberian diskon harga sehingga dapat menarik perhatian konsumen dan meningkatkan penjualan [4]. Pemberian diskon diberikan untuk produk yang akan mendekati masa

kedaluwarsa. Kemudian penelitian ini berkembang dengan adanya pemberian diskon untuk produk multy item dengan pemberian diskon dengan pertimbangan adanya backorder yang dilakukan oleh Jaya [5].

Pada penelitian ini akan dilakukan penelitian yang dilakukan oleh peneliti sebelumnya [9], [5], dan [1]. Tujuan dari penelitian ini adalah untuk menentukan jumlah pemesanan yang tepat dengan waktu yang optimal untuk melakukan pemesanan. Akan tetapi, pada penelitian ini hanya akan berfokus pada salah 1 (satu) produk yang di produksi oleh PT.X yang sering terjadi lost sales akibat faktor kedaluwarsa.

\section{METODE PENELITIAN}

Model Economic Order Quantity (EOQ) memberikan biaya total minimum karena adanya keseimbangan antara biaya penyimpanan dan biaya pemesanan. Model yang digunakan dalam penelitian ini adalah model Economic Order Quantity (EOQ) dengan mempertimbangkan masa kedaluwarsa dan unit diskon. Asumsi-asumsi yang digunakan dalam penelitian ini adalah sebagai berikut.

1. Permintaan bersifat probabilistik

2. Ukuran pemesanan konstan untuk setiap kali pemesanan.

3. Harga barang konstan.

4. Kekurangan persediaan dihitung dengan lost sales

5. Item persediaan merupakan single item. 
6. Masa kedaluwarsa diketahui.

7. Bahan baku yang kedaluwarsa tidak dapat di kembalikan ke pemasok.

Pada penelitian ini dimulai dengan menentukan total biaya persediaan dengan masa kedaluwarsa tanpa pengaruh biaya lost sales [10] adalah sebagai berikut.

Total Biaya $=P D+\frac{c_{s}}{T_{s}}+\frac{D T_{s}}{2} P H$

Dimana,

$$
\begin{aligned}
\mathrm{Ts}^{*} & =\sqrt{\frac{2 . C S}{D P H}} \\
\mathrm{Q}^{*} & =D T s^{*} \\
\text { Keterangan Notasi : } & \\
\mathrm{P} & =\text { Harga beli per unit } \\
\mathrm{D} & =\text { Permintaan per tahun } \\
c_{s} & =\text { Biaya per sekali pesan } \\
T_{s} & =\text { Lama selang waktu siklus } \\
\mathrm{H} & =\text { Fraksi biaya simpan }
\end{aligned}
$$

Total biaya pada EOQ yang mempertimbangkan adanya kekurangan persediaan [8] adalah sebagai berikut.

$$
\text { Total Biaya }=P D+\frac{c_{s}}{T_{s}}+\frac{D T_{s}\left(\frac{C_{b k}}{P H+C_{b k}}\right)^{2}}{2} P H+\frac{D T_{s}\left(\frac{P H}{P H+C_{b k}}\right)^{2}}{2} C_{b k}
$$

Keterangan Notasi :

$$
C_{b k} \quad=\text { Biaya kekurangan per unit per tahun }
$$

Dengan adanya produk yang memiliki masa kedaluwarsa, tidak menutup kemungkinan terjadinya lost sales akibat produk yang tidak dapat dijual karena masa kedaluwarsa sudah habis ataupun diakibatkan kekurangan bahan baku. Model persediaan dengan pertimbangan faktor kadaluwarsa pada kasus lost sales [5] dapat dilihat pada Gambar 1.

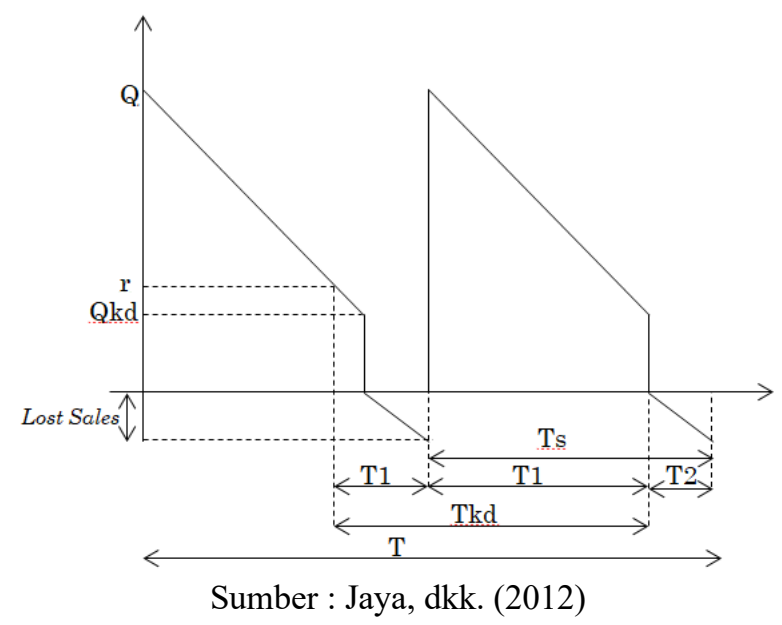

Gambar 1. Model persediaan dengan pertimbangan faktor kedaluwarsa pada kasus lost sales 


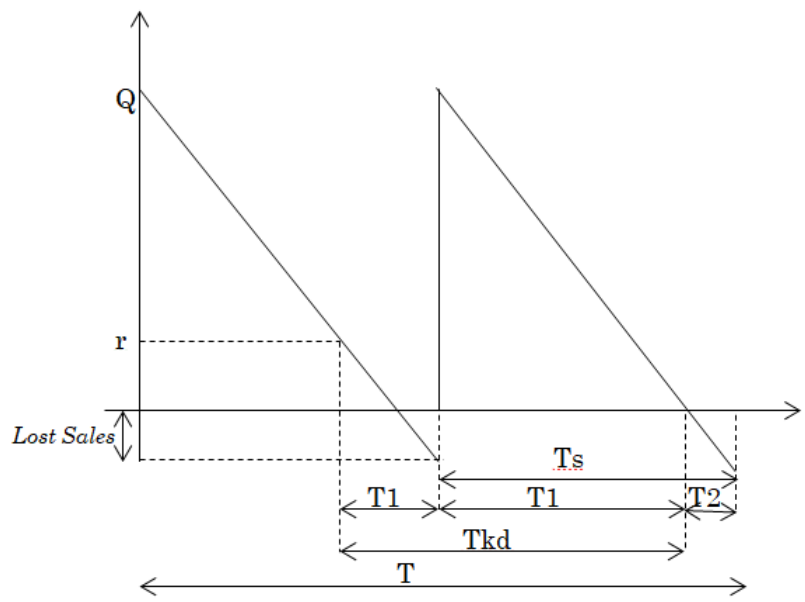

Sumber : Jaya, dkk.[5]

\section{Gambar 1. Model persediaan dengan pertimbangan faktor kedaluwarsa pada kasus lost sales (lanjutan)}

Berdasarkan Gambar 1, pada kasus produk yang memiliki masa kedaluwarsa, produk akan memiliki waktu efektif dari produk datang hingga masa kedaluwarsa $\left(T_{1}\right)$ adalah sebagai berikut.

$\mathrm{T}_{1} \quad=\mathrm{T}_{k d}-\mathrm{L}$

Keterangan Notasi :

$\mathrm{T}_{k d} \quad=$ Lama waktu kedaluwarsa

$\mathrm{L} \quad=$ Lead time

Apabila terjadi kedaluwarsa, maka terdapat selang waktu dimana tidak tersedia persediaan untuk memenuhi permintaan $\left(T_{2}\right)$. Sehingga,

$$
\mathrm{T}_{2} \quad=\mathrm{T}_{s}-\mathrm{L}
$$

Sedangkan kasus lost sales terjadi apabila $\mathrm{T}_{\mathrm{s}}>\mathrm{T}_{1}$. Pada kasus lost sales pembelian bahan sesuai dengan jumlah permintaan selama $T_{1}$. Dengan adanya diskon bahan baku, harga beli bahan baku menjadi lebih murah. Karena sering terjadi kekurangan akibat produk yang tidak terjual karena masa kedaluwarsa, perusahaan biasanya membeli bahan baku lebih dari kebutuhan. Hal ini tentunya akan mengakibatkan total biaya persediaan yang besar. Sebaliknya, jika perusahaan membeli bahan baku kurang dari kebutuhan, maka akan terjadi lost sales. Model persediaan dengan memperhatikan unit kedaluwarsa dan unit diskon pada kasus lost sales dapat dilihat pada Gambar 2.

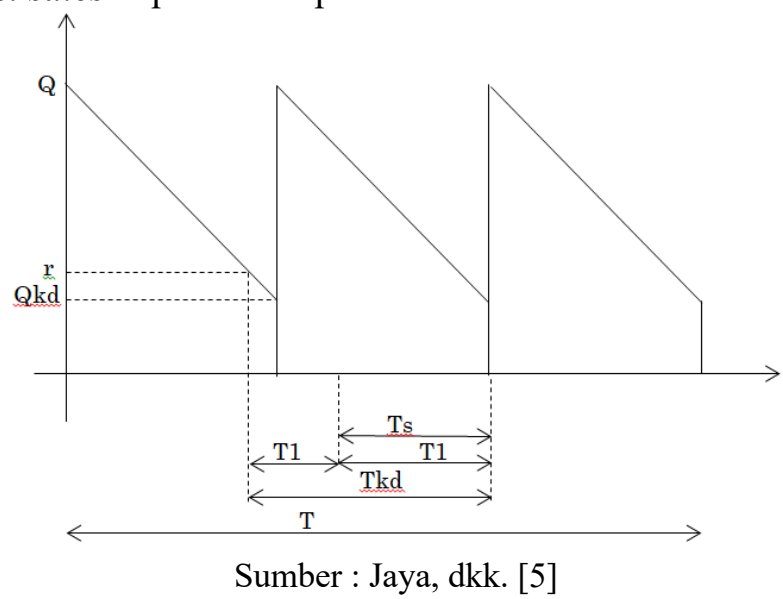

Gambar 2. Model persediaan dengan mempertimbangkan masa kedaluwarsa dan unit diskon dengan kasus lost sales 
Berdasarkan Gambar 2., total biaya persediaan pada kasus lost sales adalah sebagai berikut.

$\mathrm{TC} \quad=\frac{P Q}{T_{s}}-\frac{P_{k d}\left(Q-D T_{s}\right)}{T_{s}}+\frac{c_{s}}{T_{s}}+\frac{P H\left(2 Q-D T_{s}\right)}{2}$

Keterangan Notasi:

$\mathrm{TC}=$ Total Biaya

$\mathrm{Q}=$ Jumlah pemesanan per siklus

$\mathrm{P}_{\mathrm{kd}} \quad=$ Harga jual setelah kedaluwarsa

Dengan adanya strategi unit diskon harga bahan baku, tidak terlepas dari price break dan interval price break. Pengurangan harga suatu produk jika jumlah pemesanan produk tersebut melebihi jumlah kuantitas yang ditetapkan disebut dengan price break. Price break dilakukan sebagai bentuk penawaran kepada konsumen agar konsumen mau membeli produk dalam jumlah yang besar, sedangkan interval price break adalah rentang jarak harga jual atau selisih harga dari price break yang ditetapkan. Sebagai contoh jika konsumen membeli produk kurang dari 100 unit, maka penjual akan menawarkan harga produk sebesar Rp. 10.000/unit. Apabila konsumen membeli produk lebih dari 100 unit, penjual akan menawarkan harga produk sebesar Rp.6.000/unit, sehingga price break adalah Rp.6.000/unit dan interval price break adalah Rp.4.000.

Berdasarkan permasalahan persediaan yang telah dijelaskan sebelumnya, langkah-langkah yang digunakan untuk dapat menyelesaikan masalah persediaan dengan mempertimbangkan masa kedaluwarsa pada kasus lost sales dan penawaran diskon harga bahan adalah sebagai berikut.

1. Hitung $\mathrm{Ts}_{\mathrm{i}}{ }^{*}$ dengan menggunakan persamaan (2).

2. Jika $\mathrm{Ts}_{\mathrm{i}}{ }^{*}>\mathrm{T}_{1}$ maka $\mathrm{Ts}_{\mathrm{i}}{ }^{*}=\mathrm{T}_{1}$ kemudian hitung $\mathrm{Q}^{*}$ dengan menggunakan persamaan (3). Hal yang perlu diperhatikan dalam nilai $\mathrm{Q}^{*}$ apabila,

a. Nilai $\mathrm{Q}_{i}^{*}$ berada di bawah price break, maka perhitungan lanjut ke Langkah (3).

b. Nilai $\mathrm{Q}_{\mathrm{i}}^{*}$ berada dalam interval price break, maka hitung $\mathrm{TC}_{\mathrm{i}}{ }^{*}$ dengan menggunakan persamaan (1), kemudian lanjutkan perhitungan ke Langkah (3).

c. Nilai $\mathrm{Q}_{\mathrm{i}}^{*}$ berada di atas price break, maka tidak ada solusi yang valid.

3. Hitung $\mathrm{Ts}_{\mathrm{i}}^{*}$ dengan menggunakan persamaan (3) dengan menggunakan $\mathrm{Q}$ sebagai batas bawah pada price break. Kemudian hitung $\mathrm{Tc}_{\mathrm{i}}{ }^{*}$ dengan menggunakan persamaan (7).

4. Bandingkan nilai $\mathrm{Tc}_{\mathrm{i}}{ }^{*}$ dengan $\mathrm{Tc}^{*}, \mathrm{jika} \mathrm{Tc}_{\mathrm{i}}{ }^{*}<\mathrm{Tc}^{*}$ maka $_{\mathrm{Tc}}{ }^{*}=\mathrm{Tc}^{*}, \mathrm{Ts}_{\mathrm{i}}{ }^{*}=\mathrm{Ts}^{*}$ dan $\mathrm{Q}_{\mathrm{i}}{ }^{*}=\mathrm{Q}^{*}$.

5. Jika belum semua solusi price break-i telah dihitung, maka kembali ke langkah (1).

Jika total biaya persediaan dengan kasus lost sales dan pemberian unit diskon telah dihitung, selanjutnya adalah menghitung total biaya persediaan dengan kasus lost sales dengan mengabaikan adanya diskon harga bahan baku. Artinya perusahaan dapat membeli produk kapanpun dengan jumlah berapapun, tanpa adanya diskon harga bahan baku. Langkah-langkah penyelesaiannya adalah sebagai berikut.

1. Hitung nilai Ts dengan menggunakan persamaan (2). Jika nilai $\mathrm{Ts}>\mathrm{T}_{1}$, maka $\mathrm{Ts}=\mathrm{T}_{1}$.

2. Hitung nilai $\mathrm{Tc}^{*}$ dengan menggunakan persamaan (1) dan $\mathrm{Q}^{*}$ dengan menggunakan persamaan (3).

3. Bandingkan total biaya persediaan dengan penawaran diskon bahan baku dan lama selang waktu waktu optimal pemesanan dan total biaya tanpa pemberian diskon harga produk. Total biaya persediaan yang lebih kecil akan dipilih sebagai solusi untuk permasalahan perusahaan.

\section{HASIL DAN PEMBAHASAN}

PT.X merupakan sebuah perusahaan yang bergerak di industri makanan yang memiliki waktu kedaluwarsa pada produknya. Berikut merupakan data yang digunakan dalam penelitian ini berdasarkan pengumpulan data pada PT.X.

1. Waktu kedaluwarsa produk selama 7 hari atau sama dengan 0,019 tahun dengan lead time selama satu hari, sehingga $T_{1}$ adalah $T_{1}=7$ hari -1 hari $=6$ hari $=0,0164$ tahun

2. Total kebutuhan bahan baku selama satu tahun adalah $9.700 \mathrm{Kg}$. 
3. Biaya pembelian bahan

Harga per satuan bahan adalah Rp.7500/Kg. Pemasok sering memberikan diskon kepada perusahaan ketika perusahaan memesan bahan baku lebih dari jumlah yang ditetapkan perusahaan (price break). Diskon dari pemasok dapat dilihat pada Tabel 1.

Tabel 1. Diskon harga bahan baku dari pemasok kepada perusahaan

\begin{tabular}{|c|c|c|c|}
\hline Jumlah Pembelian & $\leq 100 \mathrm{Kg}$ & $100-500 \mathrm{Kg}$ & $>500 \mathrm{Kg}$ \\
\hline Harga Bahan Baku & Rp. $7.500 / \mathrm{Kg}$ & Rp. $6.750 / \mathrm{Kg}$ & Rp. $5.500 / \mathrm{Kg}$ \\
\hline
\end{tabular}

4. Biaya Pemesanan Bahan Baku (Cs)

Biaya pemesanan merupakan biaya per sekali pesan ditambah dengan biaya pengiriman yaitu sebesar Rp. 350.000/pesan.

5. Biaya Penyimpanan bahan baku

Biaya penyimpanan merupakan biaya yang dikeluarkan perusahaan karena terdapat penyimpanan bahan baku di gudang. Setiap bahan baku yang dipesan perusahaan tidak langsung diperoses ketika sudah datang melainkan disimpan terlebih dahulu di gudang. Perhitungan biaya penyimpanan dilakukan dengan cara mengalikan tingkat suku bunga dengan harga bahan baku. Fraksi biaya simpan merupakan tingkat suku bunga tahun 2019 adalah sebesar 9,5\% (Tingkat suku bunga mengacu kepada tingkat suku bunga yang digunakan oleh badan pusat statistic). Dengan demikian,

Biaya penyimpanan bahan baku $=$ jumlah kebutuhan bahan baku/tahun $\times$ harga bahan baku $\times$ tingkat suku bunga

$$
\begin{aligned}
& =9.700 \mathrm{Kg} / \text { tahun } \times \text { Rp. } 7.500 / \mathrm{Kg} \times 9,5 \% \\
& =\text { Rp. } 6.911 .250 / \text { tahun }
\end{aligned}
$$

Akan tetapi, dengan adanya penyimpanan bahan baku di gudang, tidak menutup kemungkinan terjadinya kerusakan bahan baku yang disimpan di gudang. Kerusakan bahan baku yang disimpan di gudang dapat terjadi karena adanya kesalahan penyimpanan, kondisi ruangan gudang, dan sebagainya. Perusahaan mengasumsikan persentase kerusakan bahan baku adalah $5 \%$ per tahun. Dengan demikian,

Biaya kerusakan penyimpanan $=9.700 \mathrm{Kg} /$ Tahun $\times \mathrm{Rp} .7 .500 / \mathrm{Kg} \times 5 \%$

$$
=\text { Rp. 3.637.500/tahun }
$$

Total biaya penyimpanan bahan baku di gudang adalah penjumlahan dari biaya penyimpanan bahan baku ditambah dengan biaya kerusakan akibat penyimpanan bahan baku di gudang.

Total Biaya Penyimpanan Bahan Baku = Rp. 6.911.250/tahun + Rp. 3.637.500/tahun

$$
=\text { Rp. 10.548.750/Tahun }
$$

6. Fraksi Biaya Simpan $(\mathrm{H})$

Fraksi biaya simpan merupakan total biaya penyimpanan per tahun dibagi dengan biaya pembelian bahan baku selama satu tahun dikalikan dengan $100 \%$. Dengan demikian,

$$
\begin{aligned}
\mathrm{H} & =[\mathrm{Rp} .10 .548 .750 /(\mathrm{Rp} .9 .700 / \mathrm{Kg} \times \mathrm{Rp} .7500)] \times 100 \% \\
& =14,5 \%
\end{aligned}
$$

Berdasarkan data-data yang diperoleh pada PT.X, dengan mengikuti langkah-langkah penyelesaian yang telah dijelaskan sebelumnya, tahapan pengolahan data dari penelitian ini adalah sebagai berikut. Langkah Pertama : Hitung $\mathrm{Ts}_{\mathrm{i}}{ }^{*}$ dengan menggunakan persamaan (2).

Jika Ts* $>\mathrm{T}_{1}$ maka $\mathrm{Ts}^{*}=\mathrm{T}_{1}$

1) Untuk harga bahan baku Rp. $7500 / \mathrm{Kg}$

Ts* $=\sqrt{\frac{2 \times 350.000}{9700 \times 7.500 \times 14,5 \%}}=0,2576$ tahun

0,2576 tahun $>0,0164$ tahun sehingga, $\mathrm{Ts}^{*}=0,0164$ Tahun

2) Untuk harga bahan baku Rp. $6750 / \mathrm{Kg}$ 


$$
\mathrm{Ts}^{*}=\sqrt{\frac{2 \times 350.000}{9700 \times 6750 \times 14,5 \%}}=0,271
$$

0,271 tahun $>0,0164$ tahun sehingga, Ts* $=0,0164$ Tahun

3) Untuk harga bahan baku Rp. $5500 / \mathrm{Kg}$

$$
\begin{gathered}
\text { Ts* }=\sqrt{\frac{2 \times 350.000}{9700 \times 5.500 \times 14,5 \%}}=0,3 \\
0,3 \text { tahun }>0,0164 \text { tahun sehingga, } \text { Ts }^{*}=0,0164 \text { Tahun }
\end{gathered}
$$

\section{Langkah Kedua}

Hitung Q* dengan menggunakan persamaan (3).

4) Untuk harga bahan baku Rp. $7500 / \mathrm{Kg}$

$\mathrm{Q}^{*}=9700 \mathrm{Kg} \times 0,0164=159,08=160 \mathrm{Kg}$

Karena $Q^{*}>100 \mathrm{Kg}$, maka Q* tidak valid.

5) Untuk harga bahan baku Rp. 6750/Kg

$\mathrm{Q}^{*}=9700 \mathrm{Kg} \times 0,0164=159,08=160 \mathrm{Kg}$

Karena $100 \mathrm{Kg} \leq \mathrm{Q}^{*} \leq 500 \mathrm{Kg}$, maka Q* valid.

6) Untuk harga bahan baku Rp. $5500 / \mathrm{Kg}$

$\mathrm{Q}^{*}=9700 \mathrm{Kg} \times 0,0164=159,08=160 \mathrm{Kg}$

Karena $Q^{*}<500$, maka $Q^{*}$ tidak valid.

\section{Langkah Ketiga}

Hitung TC dengan menggunakan persamaan (7) untuk Q* yang valid.

$$
\begin{aligned}
\mathrm{TC} & =\frac{P Q}{T_{S}}-\frac{P_{k d}\left(Q-D T_{S}\right)}{T_{s}}+\frac{c_{S}}{T_{S}}+\frac{P H\left(2 Q-D T_{S}\right)}{2} \\
& =\frac{6.750 \times 160}{0,0164}-\frac{2500(160-9700 \times 0,0164)}{0,0164}+\frac{350.000}{0,0164}+\frac{6.750 \times 14,5 \%(2 \times 160-9700 \times 0,0164)}{2} \\
& =\text { Rp. } 86.986 .901 / \text { Tahun }
\end{aligned}
$$

Langkah selanjutnya adalah dengan menghitung total biaya persediaan dengan kasus lost sales dengan mengabaikan penawaran diskon harga bahan baku. Langkah-langkah penyelesaian adalah sebagai berikut.

Langkah Pertama : Hitung $\mathrm{Ts}_{\mathrm{i}}{ }^{*}$ dengan menggunakan persamaan (2).

Jika Ts* $>\mathrm{T}_{1}$ maka $\mathrm{Ts}^{*}=\mathrm{T}_{1}$

$$
\mathrm{Ts}^{*}=\sqrt{\frac{2 \times 350.000}{9700 \times 7.500 \times 14,5 \%}}=0,2576 \text { tahun }
$$

0,2576 tahun $>0,0164$ tahun sehingga, Ts* $=0,0164$ Tahun

\section{Langkah Kedua}

Hitung Q* dengan menggunakan persamaan (3).

$\mathrm{Q}^{*}=9700 \mathrm{Kg} \times 0,0164=159,08=160 \mathrm{Kg}$

\section{Langkah Ketiga}

Hitung TC dengan menggunakan persamaan (1).

$$
\begin{aligned}
\mathrm{TC} & =P D+\frac{c_{S}}{T_{S}}+\frac{D T_{S}}{2} P H \\
& =7500 \times 9700+\frac{350.000}{0,0164}+\frac{9700 \times 0,0164}{2} 7500 \times 14,5 \% \\
& =\text { Rp. } 94.128 .369 / \text { Tahun }
\end{aligned}
$$

Perbandingan hasil perhitungan total biaya persediaan dengan pemberian diskon dan tanpa pemberian diskon dapat dilihat pada Tabel 2. 
Sri Suci Yuniar

Tabel 2. Perbandingan hasil perhitungan total biaya persediaan

\begin{tabular}{|c|c|c|c|}
\hline & $\begin{array}{c}\text { Jumlah Pemesanan } \\
(\mathbf{Q})\end{array}$ & $\begin{array}{c}\text { Lama Waktu Siklus } \\
\text { Pemesanan }\end{array}$ & Total Biaya Persediaan \\
\hline Tanpa Diskon & $\mathbf{1 6 0 ~ K g}$ & $\mathbf{0 , 0 1 6 4}$ Tahun & Rp. 94.128.369/Tahun \\
\hline Dengan Diskon & $\mathbf{1 6 0 ~ K g}$ & $\mathbf{0 , 0 1 6 4}$ Tahun & Rp. 86.986.901/Tahun \\
\hline
\end{tabular}

Berdasarkan Tabel 2., dapat dilihat bahwa total biaya persediaan dengan pemberian diskon memberikan hasil yang lebih murah dibandingkan dengan tanpa memberikan penawaran harga diskon produk walaupun jumlah pemesanan dan lama waktu siklus pemesanan dengan hasil yang sama. Pemberian diskon produk memberikan solusi penghematan untuk perusahaan PT.X.

\section{KESIMPULAN}

Berdasarkan hasil pengolahan data yang dilakukan pada bab sebelumnya, kesimpulan dari penelitian ini adalah sebagai berikut.

1. Total biaya persediaan dengan pemberian diskon memberikan hasil yang lebih murah dibandingkan dengan tanpa pemberian diskon produk yaitu sebesar Rp. 86.986.901/Tahun. Sehingga dapat memberikan penghematan untuk perusahaan.

2. Lama selang waktu optimal yaitu selama 6 hari atau 0,0164 tahun.

3. Jumlah pemesanan optimal setiap kali pemesanan adalah $160 \mathrm{Kg}$.

\section{DAFTAR PUSTAKA}

[1] Cahyo, A.D., (2014). "Perencanaan Persediaan Bahan Baku Multy Item dengan Mempertimbangkan Masa Kadaluarsa dan Unit Diskon (Studi Kasus : UD Burno Sari, Durenan, Trenggalek)", Jurnal MATRIK, Vol. XV, No.1.

[2] Djunaidi, M., Nandiroh, S., dan Marzuki, I.O., (2005). "Pengaruh Perencanaan Pembelian Bahan Baku dengan Model EOQ untuk Multy Item dengan All Unit Discount", Jurnal Ilmiah Teknik Industri, 4(2), pp. 83-89.

[3] Hsu., P.H., Wee H.M., and Teng H.M., (2006). "Optimal Lot Sizing for Deteriorating Items with Expiration Date", Journal of Information \& Optimization Sciences, 27(2), pp. 271-286.

[4] Hsu, P.H., (2012). " Optimal Ordering Policy for Fast Deteriorating Items", African Journal of Business Management, 6(30), pp. 8837-8852.

[5] Jaya, S.S., Octavia, T., dan Widyadana, I Gede A., (2012). "Model Persediaan Bahan Baku Multy Item dengan Mempertimbangkan Masa Kadaluwarsa, Unit Diskon dan Permintaan yang Tidak Konstan", Jurnal Teknik Industri, Vol.14, No.2.

[6] Limansyah, T, (2011). "Analisis Model Persediaan Barang EOQ Dengan Mempertimbangkan Faktor Kadaluarsa dan Faktor All Unit Discount", Lembaga Penelitian Dan Pengabdian Kepada Masyarakat, Universitas Katolik Parahyangan, Bandung.

[7] Limansyah, T, (2012). "Penentuan Kebijakan Pemesanan Barang Untuk Model Persediaan Multy Item dengan Mempertimbangkan Faktor Kadaluarsa dan Faktor All Unit Discount", Lembaga Penelitian dan Pengabdian Kepada Masyarakat, Universitas Katolik Parahyangan, Bandung.

[8] Muckstadt, J.A., Sapra, A., (2009). "Principles of Inventory Management: When You are Down to Four", New York: Springer.

[9] Rikardo, C.., Limansyah, T., Lesmono, D., (2015)., "Model Persediaan Deterministik Dengan Mempertimbangkan Masa Kadaluarsa dan Penurunan Harga Jual", Seminar Nasional Sains dan Teknologi, Fakultas Teknik, Universitas Muhammadiyah, Jakarta.

[10] Russel, R.S., and Taylor, B. W., (2006). "Operations Management : Focusing on Quality and Competitivenes in a Global Environment $5^{\text {th }}$ Edition", New Jersey: Prentice Hall. 